\title{
ON THE QUESTION OF CRITICAL FREQUENCY OF THE INTERMITTENT EFFECT
}

(Abstract of preceding paper)

\author{
LADISLAV ZaChOVAI \\ Institute of Physics, Charles University, Prague
}

An interpretation is given of new measurements of the influence of the frequency of light pulses on the intermittent effect, which was published in papers [6], [7], [8]. The interpretation is based on the conception of the inertia of electron processes in $\mathrm{Ag} \mathrm{Br}$. This conception has already been used in papers. [3] and [5] to explain the intermittent effect and confirmed by the results of paper [4].

The dependence is derived of the number $\xi$ of developable grains produced during intermittent exposure on the frequency $f$ of the light pulses and on the ratio $q$ of the total period $t$ of the illuminated layer to the total duration $T$ of the interrupted exposure (1).

The number $\overline{n t}$ of electrons freed by light which are needed for a certain number $\bar{\xi}$ of developable grains to be produced for a frequency $f$ is given by expression (2). With growing frequency $f$ this number becomes independent of the frequeney (3), (4).

The results of the theory are in agreement with paper (8) but not with the conclusions of papers [1] and [2].

Finally a study is made of the influence of a dark pause $t_{0}^{\prime}$ between the various light pulses on the number $\xi$ of developable grains. The results of the theory are in agreement with paper [7].

Received 23. 7. 1957.

\section{Jumepamypa - References}

[1] Webb J. H.: J. Opt. Soc. Am., 40, (1950), 3.

[2] Webb J. H.: J. Opt. Soc. Am., 23 (1933), I57.

[3] Zachoval L.: Cas. mat. fys., 72 (1947), 161. (чешск.).

[4] Мейкляр II. В.: ЖЭТФ, 21, (1951), 42.

[5] Zachoval L.: Jub. sborník 1755-1955 (Karlova universita k výročí Lomonosovy university), (1955), 283 (чешск.).

[6] Картужанский А. Л., Мейкляр П. В.: ЖЭТФ, 21 (1951), 598.

[7] Maerker R. E.: J. Opt. Soc. Am., 44 (1954), 625.

[8] Картужапский А. Л.: ЖНПФиК, 1 (1956), 10. 